\title{
International listing as a means to mobilize the benefits of financial globalization: Micro-level evidence from China ${ }^{*}$
}

\author{
Damian Tobin \\ Department of Finance \& Management Studies (DeFiMS), School of Oriental \& African Studies \\ (SOAS), University of London.

\section{Laixiang Sun} \\ Department of Finance \& Management Studies (DeFiMS), School of Oriental \& African Studies \\ (SOAS), University of London. \\ Guanghua School of Management, Peking University, Beijing, China.
}

(Revised version, December 2007)

Corresponding Author: Laixiang Sun

Address for Correspondence: CeFiMS, SOAS, University of London, Thornhaugh Street, Russell Square, London WC1H 0XG, United Kingdom. Phone: +44 207898 4821. Fax: +44 2078984089. Email: LS28@soas.ac.uk.

\footnotetext{
${ }^{*}$ We would like to thank Pauline Loong, Leo F. Goodstadt, Stuart Chiron, Angela Tse, Ashley Alder, David Li, William Lo, Mathew Yiu, Roger Luk, Simon Ogus, Steven Green and Marc Laperouza for their assistance with various aspects of the research fieldwork. We are especially grateful to the Guest Editors (Linda Yueh and Yang Yao) and two anonymous referees of this special issue for detailed and very constructive comments and suggestions.
} 


\title{
International listing as a means to mobilize the benefits of financial globalization: Micro-level evidence from China
}

\begin{abstract}
This paper proposes a micro-level framework to account for how firms in developing economies overcome domestic institutional constraints. It illustrates that the mechanisms enabling those firms to benefit from financial globalization are more complex than the "direct" financial channels outlined in the neo-classical approach. China provides an important example in this context, as its capital market liberalization has been limited and neither the legal nor financial system is well developed. Yet microlevel evidence from China's internationally listed enterprises indicates that innovative firms can overcome institutional thresholds, secure access to international capital, and benefit and learn from international capital markets. This can in turn induce market-level improvements through regulatory competition and demands for a more standardized system of economic regulation.
\end{abstract}

Key Words: International listing, globalization, regulatory competition, corporate governance, East Asia, China. 


\section{INTRODUCTION}

The question of how developing economies can improve the benefits derived from financial globalization has dominated recent discourses on global integration. The standard neo-classical approach argues that long-term financial flows from capital-rich to capital-poor countries generate welfare gains for both sets of countries. However these "direct" benefits have proved difficult to quantify and a recent revision has argued that countries first need to reach a threshold of institutional development before they can benefit from financial globalization (Kose et al, 2007). Similarly, the literature on corporate governance has mainly focused on the relationship between corporate governance and institutions, and in particular on how the quality of legal institutions determines the system of governance (La Porta et al, 2000). It suggests that in order to facilitate capital market development, emerging economies should converge towards governance systems that offer strong legal protection for investors. Yet, in developing economies, the institutions that underpin capital market development are either absent or at an early stage of development. China is a case in point. Its recent economic growth has been achieved in the absence of a well-developed law and financial system. The puzzle is deepened by the history of financial development, which shows that laissez faire was more the exception than the norm (Supple, 1976). This paper examines how developing economies can improve the benefits from financial globalization, when the institutional thresholds deemed necessary for convergence are not met.

Distinguishing itself from the macro-level approach, this paper focuses on the micro-level innovations that enable firms in developing economies to overcome institutional constraints to better governance practices, increasing their benefits from financial globalization. It explores how firms can use international listing to bond themselves to better governance practices, thereby enabling them to successfully access international financial markets. Drawing on the experiences of China's internationally listed enterprises that have implicitly used financial globalization to access international finance, and the evolution of the Anglo American system of corporate governance, it argues that the mechanisms that enable firms in developing economies to benefit from financial globalization are not necessarily the "direct" channels outlined in the neo-classical approach. It 
International listing as a means to mobilize the benefits of financial globalization:

Micro-level evidence from China

follows that the long term benefits may not be easily captured empirically in the direct financial benefits, but rather the less obvious “collateral” benefits.

Often viewed as relics of central planning, China's state enterprises are somewhat unlikely beneficiaries of financial globalization. Many operate in near monopoly conditions and retain strong ties to the state bureaucracy. Capital controls insulate domestic stock markets from the volatility often associated with international capital flows. These protections, along with a shortage of alternative investment channels and the novelty of share ownership, have meant that domestic share valuations remain high by international standards, and firms face a high opportunity cost in seeking finance on international capital markets. ${ }^{1}$ Yet, an increasing number of state enterprises have used international listing as a mechanism to access international capital markets. This has allowed them to draw not just on international finance, but also to learn from and integrate international best practices. The result is a type of globalization in reverse. Firms benefit from the oversight of international capital markets, even though the capital controls and other barriers that shield domestic markets from the direct effects of financial globalization remain in place.

The paper takes a political-economy perspective by examining the variety of ways in which firms can use international listings as a means to increase benefits and reduce risk in the process of financial globalization. First, the theoretical framework outlined in Section two describes how historically; weak legal and regulatory institutions did not necessarily impede the emergence of financial markets. Integrating the micro level into the traditional financial globalization framework allows the identification of the significant firm-level efforts to overcome these obstacles. Applying this framework, Section three draws on case study evidence to illustrate the firm-level restructuring, monitoring and learning induced by international capital markets. Section four reviews the systematic evidence at both the national and international levels. Section five outlines how micro-level improvements have induced market-level reform through regulatory competition and a more standardized system of regulation. Section six concludes.

\section{THEORETICAL FRAMEWORK}

The literatures on globalization and corporate governance raise an interesting question, namely how, if at all, do developing countries benefit from financial globalization? China provides an 
important example in this context. Although there is little doubt that China has benefited from international trade, its growth does not necessarily fit with standard theory (Allen at al, 2005). China's industrial capacity and economic growth were achieved behind high barriers (Wade, 2004). Much of the reductions in poverty occurred during agricultural de-collectivization, rather than during the subsequent trade-opening phase (Ravallion, 2006). The Asian Financial Crisis illustrated the vulnerability of China to financial crashes and the fragility of China's financial institutions (Nolan, 2004). ${ }^{2}$ In addition, political liberalization in favor of democracy and the rule of law has been limited. It would therefore be natural to assume that China does not meet the institutional thresholds deemed necessary to benefit from financial globalization. Yet, studies of China's internationally listed enterprises, regarded as China's leading corporations, suggest that it is not a necessary condition to reach the institutional thresholds in order to benefit from the international capital markets (Sun and Tobin, 2005). Nolan (2001) suggests that although China's large enterprises still lag their international counterparts in terms of managerial competencies, they are actively engaging in, and adapting to international product markets. The following section outlines the limitations of the macro perspective for China. Secondly, a historical perspective on the evolution of the Anglo-American system of governance suggests that some answers to the question of how developing economies use financial globalization can be found by examining micro-level innovations.

\section{(a) Macro level perspectives}

The persistent efforts to address the puzzle of how developing economies benefit from financial globalization have led to a revised analytical framework that analyses the "traditional" or direct benefits alongside the "collateral” or indirect benefits (Kose et al, 2006, 2007; Mishkin 2006) (see Figure 1). The revised framework acknowledges the relevance of traditional direct benefits, but in the absence of conclusive empirical evidence also argues that financial globalization can act as a catalyst for certain collateral or indirect benefits. The indirect benefits of globalization include financial market development, institutional development, better governance practices and macroeconomic discipline. Attaining these benefits is however conditional on countries reaching a series of thresholds in financial development, institutional quality and governance standards. 
International listing as a means to mobilize the benefits of financial globalization:

Micro-level evidence from China

Moreover "collateral" benefits often occur over the long-term and are not so easily captured empirically by standard models of financial development.

\section{(Figure 1 about here)}

For developing economies a difficulty with this approach is that attaining these thresholds involved a process of institutional evolution that took richer countries many decades, if not centuries to achieve. One of the most pressing problems facing developing economies is that of institution building (Kirkpatrick and Parker, 2004). Stiglitz (2000) points out that achieving financial market stability, even for a large developed economy, poses a significant challenge. For developing economies the challenge is magnified as the forces thought to promote governance convergence, including the presence of institutional investors, internationalization of markets, and competitive incentives, are largely absent. Even if a country succeeds in transplanting the developed market institutions, it would still have to deal with such obstacles as informational asymmetries and lack of enforcement experience (Pistor et al., 2000). Experience suggests that the institutions developed in richer countries do not always translate well to poorer countries; instead good institutions need to be home grown (Mishkin, 2006).

\section{(b) A historical perspective on financial globalization}

Although China's recent economic growth is often viewed as unique, the economic logic underpinning such policies as international listing is not that unlike the institutional innovations that underpinned the evolution of the Anglo-American system of governance. Although the neo-classical approach to development suggests that countries should engage in capital account liberalization in order to benefit from globalization, a second approach suggests that economic development and growth are often achieved through unorthodox institutional innovations that depart from the standard rulebook (Rodrik, 2001). A relevant example is the emergence of the Anglo-American system of corporate governance. The US corporate system, often regarded as the guardian of small investors, developed under a protectionist trade policy. The historical evolution of the Anglo-American system casts doubt upon the thesis that the US corporate form, with strong managers and dispersed shareholders is a "path dependent” political artifact (Cheffins, 2000). 
Mishkin (2006) dates the first age of financial globalization to the late $19^{\text {th }}$ century. True, the $19^{\text {th }}$ century witnessed the emergence of London as a preferred market for securities, and it attracted international listings from the US and France (Michie, 1987). However economic history indicates that large economies benefited from the so-called "collateral" effects of globalization long before this. From the $17^{\text {th }}$ century onwards, financial globalization aided the development of what is now regarded as the Anglo-American system of best corporate practice (Michie, 1987; Neal, 1978; Schubert, 1988). Coffee $(2001,2002)$ further indicates that at various stages in their history both the UK and US used micro-level innovations to become leading centers of international finance. These included borrowing financial techniques, self-regulation, and regulatory competition between stock exchanges.

\section{(c) A firm-level perspective of financial globalization}

Economic history and recent developments in China suggest that focusing on firm-level innovations can contribute to our understanding of financial globalization. One explanation for the difficulties of empirical studies on financial liberalization is the inadequacy of the macro-lens (Ravallion, 2006). In practice financial development not only occurs over a long time period, but in many cases stems from micro-level innovations (Glaeser et al., 2004). Coffee (2001) casts doubt on the direction of the causation between legal systems and corporate governance that underpins much of the law and finance literature. Others such as Clay and Wright (2005) have demonstrated the ability of agents to organize economic activity in the absence of legal protections.

Accounting for the historical evolution of the Anglo American system of governance and recent preferences for international listing in China, our approach suggests that much can be learnt about financial globalization by focusing on the firm level. This is confirmed by studies of corporate governance practices across developing economies, which reveal a large variation in governance standards, which cannot necessarily be explained by the quality and efficiency of a country's legal institutions (Pistor et al, 2000; Klapper and Love, 2004; CLSA, 2004). Table 1 reports the relevant findings in CLSA (2004). It shows a significant variation in corporate governance practices, not only across different Asian countries, but also within these countries. Average company scores tend to vary in terms of country scores. Country scores measure such issues as rules and regulations, enforcement, political and regulatory culture. Company scores also vary considerably in terms of upper and lower 
International listing as a means to mobilize the benefits of financial globalization:

Micro-level evidence from China

quartiles. Developing economies such as the Philippines, India, China and Indonesia show a marked variation between the governance practices of companies in the upper and lower quartiles. In fact the governance practices of top quartile companies in these countries are similar to those of the more developed countries in the region. Even in more developed market economies such as Hong Kong and Singapore, there still exists a variation in governance practices although these tend to be lower than in developing economies. This indicates that the relationship between governance institutions and firmlevel practice may be less clear-cut than is assumed by legal and political perspectives. In the absence of reaching institutional thresholds, many firms have already achieved the standard of corporate governance that would enable them benefit from financial globalization.

(Table 1, Figure 2 and Table 2 about here)

To account for the variations outlined above, the framework outlined by Kose et al. (2006, 2007) can be further modified by adding a firm level (see Figure 2). At the firm level, innovative firms that are willing to bond themselves and commit to higher standards of governance can overcome the barrier of institutional thresholds. By using intermediary mechanisms to by-pass threshold conditions, firms have the potential to benefit from both direct and collateral benefits of globalization. Direct benefits include finance, the standardization of property relations and better financial performance. Collateral benefits include regulatory competition, improved disclosure and transparency, better longterm access to capital and technology, organizational learning, and knowledge assimilation.

Whereas the macro-level approach views improvements as immediate once the threshold conditions are met, the micro level approach views such improvements as a consequence of longerterm commitments to better practices. There is certain inevitability in the macro-level approach, as good institutions lead to better performance with little said about how good institutions are developed. From the micro perspective, the intuition is that better institutions will follow micro-level innovations. Overtime, collateral benefits should spill over into the domestic economy thereby influencing the development of domestic institutions, driving further reform over the long term. For example, international listings should lead to the transfer of better business practices to the domestic economy and induce regulatory competition between stock markets. This incremental view of financial globalization is more consistent with the historical perspective on financial development, which 
suggests that legal and political institutions tended to confirm what had already been decided in the market place. ${ }^{3}$ Compared to the neo-classical approach, the benefits of financial globalization are achieved in reverse, and over a longer period.

\section{(d) Financial globalization in China's large SOEs}

The histories of financial development in the US and UK underscore the importance of incremental innovations at the firm and institutional level. These facilitated the borrowing of international financial techniques, the raising of large amounts of capital and ultimately led to the formation of the Anglo-American system of corporate governance. In a similar manner, China's large enterprises have attempted to overcome weak domestic institutional structures by drawing on international capital markets, particularly Hong Kong (Table 2). From 1993 onward some 100 Chinese enterprises (mainly sate-owned, i.e., SOEs) have listed foreign or H-shares on the Hong Kong Stock Exchange (HKEx). A further 52 subsidiaries of Chinese enterprises (mainly SOEs) have incorporated in Hong Kong and been listed as "red chips". The first group of SOEs listing overseas did so at a crucial time. China had no securities law, the CSRC was barely in existence and the central government was the only authority that could sanction international listings. Although Hong Kong represented the major destination for Chinese listings, the global appeal of international listing is illustrated in statistics from the Hong Kong Securities and Futures Commission (HKSFC), which show that between July to November 2005, 32 mainland enterprises (H-shares and red-chips) were simultaneously traded in Hong Kong, the US and UK. ${ }^{4}$ For these companies, $79 \%$ of the total trading value took place in Hong Kong, with $7.5 \%$ and $14 \%$ taking place in the UK and US respectively, further underscoring the importance of the Hong Kong market as a destination of choice for Chinese listings.

The attractiveness of the Hong Kong market is underpinned by strong practical benefits. Schenk (2007) points out the long history of financial relations between Hong Kong and the Mainland. These relations predated the foundation of the PRC and survived the nationalization of China's financial system during the 1950s and the radical Cultural Revolution of 1966-76. For the Mainland, Hong Kong offers access not just to finance and a wider investor base, but also the opportunity to integrate better corporate governance standards and gain greater international visibility. For Chinese 
International listing as a means to mobilize the benefits of financial globalization:

Micro-level evidence from China

firms, Hong Kong's position as a center of finance and its proximity and affinity to the Mainland give it considerable competitive advantages over competing stock exchanges in London and New York. Hong Kong's non-prudential regulatory approach is arguably much more conducive to Mainland enterprises, than the more arduous prudential supervision of the New York market. Nevertheless, just in the same manner that leading US firms gravitated towards more developed capital markets and bound themselves to high standards of governance at the end of the $19^{\text {th }}$ century, leading Chinese firms have shown a remarkable willingness to list on the Hong Kong market and comply with the high standards demanded. This is consistent with the findings of Pagano et al (2002) who show that firms from countries with weaker shareholder protection are more eager in seeking foreign listings.

Just as financial globalization can create problems for developing countries, it can also create firm-level mismatches. Weak property rights and jurisdictional issues can limit cross-border monitoring by international institutions. The task of protecting shareholder's rights in overseas listed firms that have the bulk of their assets in Mainland China is made more complicated by difficulties in establishing the rights of competing claimants. This is particularly problematic in Mainland subsidiaries where property rights are less well defined. ${ }^{5}$ Orders against the reporting of certain cases mitigate the effectiveness of improved disclosure. ${ }^{6}$ International Listing also creates specific challenges for bureaucratic styled management. There is an inherent misalignment between the traditional "political skills" of SOE management and the expectations of international investors. Reforms created ambiguities as to how former bureaucrats were to behave under market conditions and how they could be trained to do so (Hsu, 1991). There is also a large political cost to financial globalization. China's internationally listed enterprises are ultimately subject to the political control of the Chinese Communist Party (CCP). Threats to this control or the revelation of corruption carry an implicit political cost. However, regardless of the costs associated with financial globalization, the CCP appears to have recognized that at the firm level there is little option but to reform.

\section{THE FIRM LEVEL BENEFITS OF INTERNATIONAL LISTING}

One of the most significant aspects of foreign capital is that it carries a much greater obligation to repay. In the Chinese context, although many international listings were capital-raising events, capital was often not the primary concern. Much more important was the range of 
commitments and opportunities that were attached to international capital. Moreover, focusing on the direct financial benefits does not conclusively answer the question of why firms access international capital markets. Drawing on the firm-level framework outlined in Figure 2, this section explores the micro level and its relationship to financial globalization. Focusing first on the direct financial benefits, it points out that there is an implicit opportunity cost to using international capital markets. This cost is however mitigated, if not completely diminished, by the improvements in governance, organizational learning, and the knowledge and technological transfers that accompany international listing.

To illustrate how this occurs in practice, we first draw on case studies of firms in three centrally regulated sectors: banking, telecommunications and petrochemicals. The enterprises examined include the Bank of China (Hong Kong) (BoCHK), which, as the first international listing of a subsidiary of a state-owned commercial bank, represented a pioneering banking reform. In the telecoms sector, the international listings of China Unicom and China Mobile marked a significant departure for what was previously a political and militarily strategic industry. In the petrochemical sector the international listings of Shanghai Petrochemical Company (SPC), one of the first SOEs to list abroad, and its parent Sinopec, represented a major reform for a sector once regarded as a model of Maoist production. As enterprises that previously formed the backbone of central planning, the selected cases were somewhat unlikely participants, let alone beneficiaries of financial globalization. Yet, in each case international listing was used to achieve outcomes that are typically associated with reaching institutional thresholds of legal and regulatory development.

From a methodological perspective case studies are particularly suited to identifying microlevel changes as they have apparent advantages where qualitative data prevail and there are more variables than data points. Case study data include formal semi structured interviews with enterprise directors and regulatory agencies, in addition to published data. A potential disadvantage is the question of how representative the cases are. The cases we selected are representative of their respective sectors and centrally regulated sectors generally. China Mobile and China Unicom are dominant players in the telecom sector and each accounting for more than $40 \%$ of the market. Sinopec is the largest player in the petrochemical sector and controls about $51 \%$ of China's refining capacity (Kamabara and Howe, 2007). Bank of China (BoC) is the second largest bank in China with a market 
International listing as a means to mobilize the benefits of financial globalization:

Micro-level evidence from China

share of more than $17 \%$ and BoCHK is the largest spun-off subsidiary of BoC (Sun and Tobin, 2005).

To address the generalization issue, we also provide survey type evidence at both the national and international levels in section four.

\section{(a) The direct financial benefits}

The traditional view of globalization typically emphasizes the potential financial benefits for developing economies (Figure 1). While international listing has undoubtedly been successful in terms of the volume of capital raised (Table 2), the overall financial benefits are not conclusive. Enterprises listing in Hong Kong faced a large opportunity cost relative to listing on Mainland stock markets. Better share price performance, higher valuations, and cheaper finance without the transaction costs associated with international listing, could have been achieved using domestic capital markets. Throughout the 1990s and into the early 2000s, enterprises listed on Mainland markets traded at much higher multiples (cf. Figure 3). In 2000 the Price Earnings ratio for the Shanghai Index stood at 59 times earnings compared to an earnings ratio of nine times for H-share Index in Hong Kong. The “China Enterprises Index” in Figure 3 illustrates how Chinese enterprises listed in Hong Kong were originally valued less than their counterparts in Hong Kong and Shanghai. These valuations have since converged with the Hong Kong market generally, not least because of their strong role on the Hong Kong market. Similarly, since 2003, an oversupply of poor quality shares on the Shanghai market has seen valuations decline towards Hong Kong levels. Although the opportunity cost of raising finance has declined in recently, the implication is that the finance motive should not be treated as conclusive. $^{7}$

A second direct effect of financial globalization is its effect on performance. The intuition underpinning privatization generally is that the social functions of SOEs are replaced with the objective of profit maximization. Domestic privatizations in China have typically been hampered by the problems of related party transactions and asset stripping (Green, 2004). In theory international listing provides a more credible means of monitoring management (Sun and Tobin, 2005). In practice, the post-privatization performance of China's internationally listed enterprises suggests few quick benefits from using international capital markets (Table 3). Declining average financial performance with increasing standard deviation suggest that the direct benefits of financial globalization are not 
immediately obvious, except for a few leading firms. ${ }^{8}$ Enterprises appear to have achieved pre-IPO improvements in preparation for international listing. However, similar to other studies on privatization, in many cases these improvements have hardly been maintained over the longer-term. ${ }^{9}$

(Figure 3 and Table 3 about here)

\section{(b) International capital markets and external monitoring}

The high opportunity cost of international listing and the limited improvements in financial performance suggest that from the perspective of the firm, the rationales underpinning international listings are more complex than capital-based explanations. This view is confirmed at firm level. For firms, capital markets offered a means of devolving the supervision of enterprise reforms to external institutions. The BoCHK cites important business and self-regulatory considerations underpinning the decision to pursue an international flotation. ${ }^{10}$ From a business perspective the bank had the objective of transforming a loosely aligned business, consisting of 12 separate banks, into a structure that was capable of competing with other Hong Kong banks. A second and arguably more significant reason is that it would force the bank to adopt a more appropriate form of governance by subjecting itself to external market discipline. Inertia and bureaucratic resistance often frustrated previous attempts at reform. With international listing, the pressure comes from an external source. A crucial issue cited by the bank, was that the main emphasis of the IPO was on restructuring rather than raising equity. The bank gained no additional funds from the IPO. Interestingly an executive at the bank noted "when a firm has the maximization of funding as its prime reason for listing, there is an incentive to conceal issues...for the BoCHK, improving corporate governance was an objective so coming clean was very important." ${ }^{11}$ By putting governance reform to the fore of its floatation, the Bank effectively subjected itself to more rigorous disclosure practices.

Similar motivations are evident in the other sectors examined. An executive at Unicom, China's second largest telecoms provider noted "from an overall perspective, (with domestic listing) you would not have incremental value and exposure to standards as with international IPO.” ${ }^{12}$ In this regard international capital markets are important, not so much for raising capital, but rather the range of commitments and learning that come with it. A deputy director at Sinopec, China's largest petrochemical refiner summed up the process by noting that while the role of the WTO is to speed up 
International listing as a means to mobilize the benefits of financial globalization:

Micro-level evidence from China

economic reforms, "the purpose of listing is to reform the management of SOEs."13 Prior to listing, production units were simply obliged to report production indices and profits to the state. International listing meant that profits now had to be reported to shareholders. It also came with a commitment to reduce costs and become more transparent. Sinopec committed to cut 100,000 workers from its 510,000 strong workforce and reduce costs by US $\$ 1.6$ billion. ${ }^{14}$

The above suggests that international listing formed part of a general long-term reform effort to subject enterprises to international corporate practices. Even before China's enterprises listed on international stock markets, most large international companies already had some sort of business dealings in China. This is important as it indications that the purpose of international listings was to bring China's large enterprises to the attention of the international investment community. Sinopec acknowledged that international listing represented a progression of political efforts to improve SOE performance. "The government wanted its enterprises to engage in international capital markets as it gave them more exposure to international business practices." ${ }^{15}$ In terms of capital, foreign investors became shareholders rather than revenue sharing partners. This is not to say that foreign investors did not play an important function. Unicom noted that the global mix of investors has created a type of dynamism within the firm that has forced management to do better. Preparation for listing induces enterprises to become more efficient and external market monitoring ensures that this efficiency is maintained.

\section{(c) Improvements in disclosure and transparency}

Although the retention of controlling shares by the state meant that the role of foreign investors was somewhat limited, international capital markets did provide an important source of external monitoring through the due diligence process. Although the HKEx is highly regarded, it is not a prudential regulator. Both the HKEx and the HKSFC rely to a large extent on the integrity of the due-diligence process. ${ }^{16}$ The due-diligence process makes it much more difficult to hide off-balance sheet commitments and guarantees to related parties. Significantly, despite the concern over related party transactions between Hong Kong listed enterprises and their mainland parent companies, securities regulators in Hong Kong reported that listed state enterprises from China were no more problematic than other classes of company listed on the Hong Kong market. ${ }^{17}$ In fact their property 
rights structures were much more straightforward than the more complicated Asian family business structure, which the Hong Kong market has traditionally financed.

How the due diligence process worked in practice is clearly illustrated in the international flotation of the BoCHK in 2002. Due diligence of the bank's operations brought into the public domain significant information regarding the operation of a bank generally regarded as plagued by high information asymmetries. Preparation for listing forced a house clearing of third world practices generally, with the revelation of a range of irregularities both abroad and within the Bank's domestic operations. ${ }^{18}$ The diligence associated with listing was not a once off event. The aftermath of the IPO led to further revelation of wrongdoing. In June 2003, the bank’s Chief Executive, Mr Liu Jinbao, resigned from his position and returned to Beijing as part of a "routine" transfer. Later it emerged that Liu had approved a loan to a disgraced Shanghai property tycoon. In August 2004, two of the banks Deputy Chief Executives were suspended and transferred to Beijing. This time, the offence involved the alleged unauthorized distribution for personal benefit of funds belonging to the controlling shareholder of the former constituent banks. ${ }^{19}$

Although these events created certain jurisdictional issues, the overall effect was to send a clear signal that corruption and mal-practice were incompatible with international capital markets. Moreover the monitoring effect of international markets is much more consistent. The effect of external monitoring imposed by international capital markets is best summed up in the statement that “before listing you could do all kinds, regulation was not stringent. Now you can't just do it your way. Listed companies also have an expectation to perform." ${ }^{20}$

\section{(d) Technology transfer}

An important feature of China's large industrial enterprises is the high level of technical competence and their ability to source technology abroad. This would suggest that financial globalization was unnecessary for technology transfer. In the telecom and oil sectors, the level of internal technical competence does not appear to have been a significant constraint. Most executives at China Mobile and Unicom had long backgrounds in engineering or local postal and telegraph administrations. Management at Sinopec was comprised of engineers with vast industrial experience. ${ }^{21}$ It had also developed its own "good technology" for drilling and exploration. ${ }^{22}$ The interest in China 
International listing as a means to mobilize the benefits of financial globalization:

Micro-level evidence from China

shown by multi-national oil and telecoms companies meant that modern technology could be easily purchased, and was not a central motivation for listing abroad. In the telecoms sector the willingness of foreign firms to sell network technology gave China significant choice over what type of network to adopt. In the oil sector China began importing refining technology from the West as early as the 1960s (Williams, 1975). Therefore long before listing, large foreign oil companies had some business dealings in China.

International capital markets did however offer a mechanism to access proprietary technology through improved reputation. For SOEs with ambitions to compete internationally, quality has become a key issue. New technologies are often proprietary and harder to develop domestically. Firstly, international listings provided management with the autonomy and incentives to engage international partners. Secondly, it improved their international reputation. Unicom expressed the view that the international IPO process is interlinked with technology transfer. Although technology can be relatively purchased easily, entering an international partnership offers access to a much more sustainable source of new and proprietary technology. A company with an international listing is likely to have a better international reputation and is therefore less likely to engage in potentially damaging intellectual property disputes.

In the petrochemical sector, similar motivations existed. Much of the technology upon which the sector was founded originated from the former Soviet Union and was now dated. Management also faced the challenge of substituting labor with modern technology. When Sinopec listed in 2000, it was already achieving refining yields of over 90 percent. With high levels of capacity utilization and yields, there was limited scope to increase capacity internally. The challenge was to build new capacity. ${ }^{23}$ This is not so easy to achieve domestically. Chemical refining has become more technical, as refiners not only have to deal with low quality domestic inputs, but are also expected to produce to a higher standard, in order to compete with international products. As early as the 1970s, Sinopec imported refining equipment and technology from $\mathrm{ABB}$, an international company specializing in ethylene purification technology. ABB later agreed to invest US\$100 million in Sinopec’s IPO. ${ }^{24}$ Such leading international exploration and refining companies as Exxon Mobil, BP and Shell all took strategic shareholdings in the company's IPO. While Sinopec cited strategic investors as important for inspiring 
investor confidence in its IPO, there is also reason to believe that they needed these companies for strategic alliances. Refining technology tends to be proprietary and Sinopec acknowledged that for technology on the chemical side it was necessary to engage in international joint ventures. ${ }^{25}$ As part of its IPO, Sinopec appeared unusually willing to grant incentives in order to encourage strategic investors. It negotiated a deal with Exxon Mobil allowing it access to a joint venture in gasoline stations. ${ }^{26}$ Exxon possessed important proprietary hydrocarbon technologies.

\section{(e) Organizational learning and knowledge}

China’s large enterprises have used international listings to facilitate learning and knowledge assimilation in order to overcome deficits in managerial competencies. Conceptually, learning is reflected in an enhancement of organizational competencies, which should overtime reduce the risk of organizational mortality (Levinthal, 1991). Related to the concept of learning is that of knowledge. Amsden (2001) distinguishes between asymmetries of information and knowledge. From the perspective of transaction cost economics, financial globalization holds the prospect of reducing informational asymmetries. This however says little about the contribution of a firm's knowledgebased resources. The conceptual nature of knowledge implies that its presence will largely depend on firm-specific qualities. Like information, knowledge may also be imperfect, the implication being variations in productivity across sectors (Amsden, 2001).

Organizational learning and the assimilation of knowledge has been an implicit feature of international listing. The policy of listing smaller subsidiaries first known as "marrying the prettiest daughter first" has allowed enterprises to draw on the experiences of earlier listings. The listing of the BoCHK was viewed by many as a market test for the listing of its parent company the BoC, and the more problematic state commercial banks. After the listing of BoCHK, the BoC was restructured into a shareholding company, carried out an overhaul of top management structures, ${ }^{27}$ and was listed on the HKEx in 2006. Following the experiences of BoCHK, the BOC recruited directors with international banking and regulatory experience. It also appointed directors from the BoCHK to its board in advance of listing. This allowed the BoC to draw on the knowledge and experiences gained from the listing of BoCHK. An often-overlooked feature of this approach is that it provides a promotion mechanism to reward the learning of enterprise management. The listing of the better 
International listing as a means to mobilize the benefits of financial globalization:

Micro-level evidence from China

performing provincial mobile licenses first in China's telecoms sector was indicative of a similar approach.

The petrochemical sector provides a specific example of how learning and knowledge assimilation occur. The listing of SPC in 1993 provided its parent company Sinopec with some valuable lessons on the functioning of international capital markets. If compared to other state enterprises that listed in the same year such as Tsingtao Brewery (110 times oversubscribed) and Guangzhou Shipyard (77 times oversubscribed), SPC at 1.2 times subscribed failed to make an impact in terms of investor demand. ${ }^{28}$ When Sinopec listed in 2000, management had much greater market experience to draw upon. In the first instance they were able to draw on the directors involved in the listing of SPC. ${ }^{29}$ In 1994, Wang Jiming, the chairman who oversaw SPC’s public listing was made deputy general manager at Sinopec. Based on past experiences, Sinopec placed considerable emphasis on restructuring its operations to bring them in line with international management practices. The poor reception that SPC received taught management that an integrated structure was easier to sell to investors as it reduced overlapping functions and competition between subsidiaries. Integrating upstream and downstream operations also allowed Sinopec to absorb price increases on the input side, thus lessening its exposure to international price variations. ${ }^{30}$

In the banking sector the emphasis has been very much on using foreign directors as an important source of introducing international banking practices. For the BoCHK international directors represented an important source of knowledge, or "a shoulder to lean on" for the "Beijing” directors. ${ }^{31}$ Since 2004 it has been bank policy to involve independent directors in the recruitment of senior management. ${ }^{32}$ Independent directors have become an integral part of the operation of the bank. Prior to their appointment, no one at the bank would have considered having meetings through English or providing translations. They have made life much easier for the "Beijing" directors, most of who are executives at the BoC, as they now have someone to turn to for advice, further enhancing learning and knowledge assimilation within the organization.

\section{SYSTEMATIC EVIDENCE ON GOVERNANCE}

The case studies provide micro-level evidence of how firms in centrally regulated sectors benefit from financial globalization. However given the uncertainties surrounding the direct 
"financial" benefits, it is difficult to articulate how, if at all, these micro-level innovations are leading to a systematic and quantifiable improvement. In fact the micro-level analysis suggests that improvements should be most obvious in the area of governance. To establish if this is the case, this section examines how international listing has led to a quantifiable improvement in general governance practices vis-à-vis domestic listed firms using credit ratings and survey evidence. These two sets of comparison indicate that the crucial difference lies between international and domestic listing.

In developed economies company ratings mainly provide a comparable measure of a firm's reputation and creditworthiness, given the limited measurable variations across firms in corporate governance structures and practices (Black, 2001). In contrast, in a developing economy like China, rating agents typically pay much more attention to corporate governance concerns due to the fact that the low quality of average governance practices in the economy leaves huge room for inter-firm variation. For example, of the seven firm-specific risk factors in the XFN-Far East China Credit Rating's criteria, four deal with corporate governance concerns, which include management quality, organization structure, relationship with parent company, major shareholders and government, and disclosure practices. ${ }^{33}$ As ratings are based on international criteria, they therefore provide a useful proxy for measuring the extent to which international listing has enabled China's SOEs to achieve internationally comparable levels of governance practice. XFN-Far East China Credit Rating provides comprehensive and reputable company credit ratings for China (The Economist, 24/05/2003). Poon and Chan (2007) present robust econometric evidence to show that this agency's rating does have information content and influences investment decisions. XFN ratings are instructive for our purpose in two ways. First, they show how internationally listed state enterprise have achieved intentionally comparable standards of governance. Secondly they illustrate a robust disparity of creditworthiness between the sample of internationally listed companies and that of domestically listed.

Table 4 reports a summary of the XFN-Far East China Credit Ratings on August 2007. Of 152 internationally listed companies, 36 (23.8\%) were qualified for the PI rating (i.e. based on publicly available information). In contrast, of 1434 domestically listed companies, 164 (11.4\%) were qualified for the PI rating. Of the 36 internationally listed companies with the credit ratings, $61.1 \%$ (22 
International listing as a means to mobilize the benefits of financial globalization:

Micro-level evidence from China

companies) achieved rating of A- or above. The corresponding figure for domestically listed peers is 28.6\% (47 companies). Table 4 also shows that the numbers of domestically listed enterprises figure much less prominently in the highest ratings. None of the domestically listed enterprises achieved the top rating of AAA and only one achieved AA+. In sharp contrast, four internationally listed companies achieved AAA and the other two achieved AA+. In addition, an intra-industrial comparison indicates that except for five cases in the automobile, electric appliance, iron and steel, and telecom, internationally listed companies typically achieved a higher or equal rating in comparison with their industrial peers which listed domestically.

The above disparity is also reflected at the international level. The United Nations Conference on Trade and Development (UNCTAD) conducted three surveys in 2004, 2005, and 2006 respectively to review status of corporate governance disclosure. The survey at each time drew sample firms from the top ten largest enterprises within each region and chose a sample size of about 100 . Three reviews consistently suggest that SOEs with only a domestic listing have a tendency towards lower rates of disclosure than those with an international listing, and that internationally listed SOEs tend to have rates of disclosure comparable to global best practice, while non-listed and only domestically-listed SOEs tend to be among those with the lowest rates of disclosure (UNCTAD, 2006).

Taken together, the above evidence indicates that even in an economy with weak legal system and weak norms governing behavior of corporations and their insiders, individual corporations can take it upon themselves to achieve better governance practices and higher credit ratings, thereby reducing their costs of capital financing. Such a self-selection process may be regarded as problematic in a pure statistical sense; it however does represent a strategic move for innovative enterprises to distinguish themselves from their local peers and is consistent with the evolution of the AngloAmerican system.

\section{MARKET LEVEL IMPROVEMENTS}

While micro level evidence indicates that international listing has enabled firms to improve their benefits from financial globalization, less clear is how these benefits can induce market level improvements. At the outset, equity market liberalization has been limited and capital account transactions are tightly controlled. There also remain considerable social, economic and historical 
obstacles at every level to better corporate practices. Prior to the 1990s, little market-based cooperation or oversight existed. However just as financial globalization has induced reform at the firm level, it has also injected an element of dynamism into domestic institutional reforms. Two developments related to international listing are important in this context. First, the migration of Chinese companies towards Hong Kong and New York has created a more competitive environment for listings and equity investments. Coffee (2002) differentiates these improvements, which he refers to as regulatory competition, from the type of firm bonding outlined in the previous two sections. Regulatory competition is driven by efforts to stem the migration of companies abroad and is characterized by the move towards higher standards in domestic markets. Secondly, the listing of firms abroad and their exposure to international standards has led to a demand for greater standardization in the domestic business environment. The appendix outlines the key events marking China's regulatory evolution and market level improvements. The following two subsections provide a more detailed assessment.

\section{(a) Regulatory competition}

As noted earlier, the emergence of NYSE at the end of $19^{\text {th }}$ century was underpinned by its ability to market itself as a listing destination for good quality shares. By offering shareholders strong protection, the NYSE became one of the words leading markets, stemming the migration of US firms to European financial centers. To this day the NYSE continues to be viewed as a guardian of investor interests. The migration of better governed enterprises to Hong Kong and other international financial markets presents China's stock markets with a similar challenge. Xi (2006a) argue that one of the effects of economic globalization is that it has put the CSRC under competitive pressure to adopt higher standards of corporate governance. China's response has been significant not just for the measures introduced but also to the extent that they have followed the US model of mandating corporate governance practices.

China's first securities legislation was introduced in 1999 and a code of corporate governance for listed companies followed in 2001. Both were essentially codes of best practice based on international practices. The Securities Act of 2005 went a step further by increasing the level of legal protection afforded to individual Chinese investors. It prohibits any publicity or leaking of information 
International listing as a means to mobilize the benefits of financial globalization:

Micro-level evidence from China

before such information is announced, standardizes securities dealing and underwriting and penalizes issuers for use of funds in ways other than stated in their offering documents (Wu, 2006). It empowered investors to seek damages for losses incurred against insiders who trade on inside information (Xi, 2006b). However one of the most significant reforms was the mandatory requirement that at least one-third of the board be independent, and that listed companies create audit and remuneration committees, both of which would have a majority of independent directors (Xi, 2006a). In addition boards were required to have a supervisory board, similar to that of German corporations. Company Law was also reformed with a revised law coming into force in January 2006. This reduced the all powerful role of the chairman by providing that a director or manager may serve as the legal representative of the firm (Wu, 2006).

Not only was the codification of board structure in law unprecedented, but it also signaled the clear intention of Chinese regulators to move towards a type of prudential market regulation typically associated with the US. China's mandatory approach to board composition is somewhat similar to the rational followed in the US where the legislature has acted when the interests of investors and the integrity of markets are perceived to be at risk. The Sarbanes-Oxley Act of 2002 mandated much corporate governance including the structure of boardroom committees (Roe, 2005). Although it is widely acknowledged that enforcement problems and the misalignment of incentives remain, financial globalization has undoubtedly induced regulatory competition in China even though many restrictions on capital flows remain.

\section{(b) Standardized regulation}

The second market level effect has been more subtle. Because of enforcement problems, codifying corporate governance requirements in law is likely to have limited effects in the short term. Indeed early utility regulation in the US emerged as a response to market developments, and a crystallization of public opinion against monopolists, rather than a legal abstraction (Dillon, 1925). Firms often demanded regulation as a means of avoiding competition (Demsetz, 1968). Ultimately to be successful, regulations need to be enforceable. The success of the "regulated monopolist" in the US was dependent on the establishment by the state, of a legal system and pricing structure that was supportive of innovation and competition (Bates, 1997). International listing has witnessed increased 
efforts for improving regulatory cooperation between China and Hong Kong and has also seen enterprises demand a more standardized form of regulation.

The first listings witnessed the signing of Memorandums of Understanding on regulatory cooperation between the HKSFC and CSRC and the requirement that Chinese listings abide by the rules of the Hong Kong stock exchange (Zhu, 2001). In practice cross-jurisdictional cases have typically proved problematic for regulators in Hong Kong, as mainland probes into officials tend to take months to complete, with political considerations carefully weighed against financial and legal implications. ${ }^{34}$ The recall to Beijing of Mr. Liu as head of the BOCHK in 2003 illustrates the practical limitations of financial globalization. Authorities in Hong Kong had no opportunity to investigate Mr. Liu's actions. An official at the HKMA reported that he was as baffled as the public on Mr. Liu's situation. ${ }^{35}$ These type of problems stem from fundamental differences between the two legal systems, particularly the difficulty of reconciling Hong Kong’s case law with China’s legal codes (Zhu, 2001).

Yet these difficulties have also provided a platform for greater cross-jurisdictional cooperation. In April 2007, both the HKSFC and the CBRC signed a Memorandum of Understanding on the further enhancement of the regulatory co-operation. The purpose of this was to put in place a framework for the commencement of regulatory co-operation, mutual assistance and information sharing, to allow both authorities to promptly identify risks, and adopt regulatory measures to protect investors.

It is also clear that the prospect of international listing offers firms, even in troubled sectors of the economy a powerful incentive to reform. In China's state commercial banking sector the urgency of banking reform is well known, particularly in advance of the eventual opening of the China's banking market to foreign competition. Under the transition there exist few constraints for limiting demand and few measures for making borrowers bear the full cost of investing inefficiently (McKinnon, 1991). According to the Governor of the PBOC, "only when agencies at the micro-level put in place risk control and capital constraint, could monetary policy transmission mechanism work” ${ }^{36}$ In 2004 Vice-Premier Huang Ju emphasized the need to learn from international practices, to explore a route of supervision that complies with China's real conditions and international norms. ${ }^{37}$ Offering state banks the incentive of an international listing in return for reform is pushing even the most problematic state banks to improve financial performance. ${ }^{38}$ 
International listing as a means to mobilize the benefits of financial globalization:

Micro-level evidence from China

Being listed on international stock markets has also increased enterprise demands for more standardized regulatory pricing structures. In the telecoms sector, corporate executives are clearly aware of international investors demand for increased shareholder value. However, at provincial level, price regulation is weak and it is political benchmarks that matter. As a consequence local managers tend to discount prices to enhance political standing. In the oil sector, increasing oil imports meant that listed firms were often at a disadvantage, as changes in the international oil price were not reflected in the state price. Differentials between the state price and the international price of crude can hurt the profitability of state producers whose profit margins are increasingly determined by market prices. The state price is often more driven by political and social considerations than market fundamentals. This in turn creates regulatory risk for investors leading to a situation not unlike that faced by European investors in the US in the $19^{\text {th }}$ century who financed large infrastructure projects with little expectation of a financial return.

\section{CONCLUDING REMARKS}

This paper set out to examine how international listing could serve the purpose of strengthening the benefits and the reducing risks associated with financial globalization for a developing economy like China. Departing from the conventional macro lens, it instead focused on the micro-level innovations that enable firms in developing economies to overcome institutional constraints to better governance practices. It described how micro-level innovations not only formed the basis for the evolution of the Anglo-American system of governance, but how they are being employed by China's large enterprises. International listings have not only led to the transfer of better governance practices in China's large SOEs but have also induced regulatory competition at the market level. The findings further confirm China's incremental approach to development. Firms have benefited from the oversight of international capital markets, even though the capital controls and other barriers that shield domestic markets from the direct effects of financial globalization remain in place. Our findings are in line with those on internationally listed stocks of Central and Eastern European firms (Korczak and Bohl, 2005), cross-listed stocks of US and EU companies (Pagano et al. 2002) and survey evidence from UNCTAD (2006). The policy implication is that just as providing technical assistance to developing economies often proves more fruitful than financial aid, promoting 
the mechanisms that assist the transfer of skills and knowledge may improve the benefit-risk calculus of globalization at the firm level.

There are also significant opportunity costs to international listings. Listing exposes management to a type of external monitoring that they would have had little previous experience. International IPOs do not necessarily lead to the type of performance improvements predicted by privatization theory. Chinese firms listed in Hong Kong also have lower valuations and are priced more closely with market fundamental than their Mainland counterparts. Yet, if anything, these costs underscore the significance of international listings and the role of international capital markets to China's future integration into the world economy. Given the huge political dimension to China's large enterprises, it is unlikely that these costs would be borne if the long term economic payoff was not significant.

While the micro level approach generates insights into China's rapid development in the absence of well-developed legal and financial systems, it should be regarded as complementary rather than substitutive to the macro-level approach as indicated in Figure 2. Although leading firms in developing economies can overcome institutional thresholds, secure access to international capital, and in doing so learn from international capital markets, it would be difficult for the majority of firms in the economy to fully utilize these benefits unless certain levels of thresholds associated with institutional quality and financial sector development can be attained. 
International listing as a means to mobilize the benefits of financial globalization:

Micro-level evidence from China

\section{Notes}

${ }^{1}$ A study by the McKinsey Global Institute (2006) pointed out that on average, shares listed both in Hong Kong and in Mainland China (A-shares) trade at a 50 percent premium on the Mainland.

${ }^{2}$ The bankruptcy of GITIC and the insolvency of Guangdong Enterprises are cases in point (Nolan, 2004: 49).

${ }^{3}$ For examples see Clay and Wright (2005), Glaeser et al (2004) and Pratt (1980).

${ }^{4}$ Trading of Mainland Stocks and HSI Constituent Stocks in Hong Kong, the UK and US, Hong Kong Securities and Futures Commission (2005), Research Paper No. 25.

5 “Shanghai Land hit by new claim" SCMP, June $23^{\text {rd }} 2003$.

6 “Avoid graft case, journalists told" SCMP, June $16^{\text {th }} 2003$.

${ }^{7}$ Similar comparative results hold for Shenzhen Stock Exchange, although not reported here.

${ }^{8}$ Interestingly Table 3 presents a more sanguine picture of long-term performance than that provided for Ashares by Wang et al. (2004), who find more immediate worsening in financial performance of domestic listings.

${ }^{9}$ Dewenter and Malatesta (2001) find that much of the improvement in profitability occurs in the three years before the government reduces its shareholding indicating that preparation for privatisation may induce restructuring.

${ }^{10}$ Interview: Executive Director, Bank of China (Hong Kong), Hong Kong, July $20^{\text {th }} 2004$.

${ }^{11}$ Interview: Executive Director, Bank of China (Hong Kong), Hong Kong July 20 2004.

${ }^{12}$ Interview: Executive Director, China Unicom, Hong Kong, July $26^{\text {th }} 2004$.

${ }^{13}$ Chen Ge, Deputy Director Sinopec quoted in Business Week, October $23^{\text {rd }} 2000$.

14 “Investors to China: Open those Books” Business Week, October $23^{\text {rd }} 2000$.

${ }^{15}$ Interview: Board Representative, Sinopec Head Quarters, Beijing August $12^{\text {th }} 2004$.

${ }^{16}$ Interview HKEX, July $22^{\text {nd }}$ 2004, and HKSFC, July $5^{\text {th }}$ 2004. Securities regulation in Hong Kong is likely to become more prudential to bring the Hong Kong into line with international practice.

${ }^{17}$ Interview with HKEx July 22 ${ }^{\text {nd }}$ 2004; HKSFC July $5^{\text {th }} 2004$.

18 "Irregularity committed by BOC branch in New York", Peoples Daily, March 6 2002.

19 “Lender hit by new scandal” The Standard (HK) August $4^{\text {th }} 2004$.

${ }^{20}$ Interview: Executive Director, China Unicom, Hong Kong July $26^{\text {th }} 2004$.

${ }^{21}$ Despite the low level of technology, considerable effort was invested into research, as is evident by the publications on refining in Chinese Scientific Journals during the 1950s and 60s (Williams, 1975: 244).

${ }^{22}$ Interview: Board Representative, Sinopec Head Quarters, Beijing August $12^{\text {th }} 2004$. 
${ }^{23}$ Interview: Board Representative, Sinopec Head Quarters, Beijing August $12^{\text {th }} 2004$.

24 “ABB investing US\$100 million in China Sinopec Corp. IPO” ABB Press Release (Zurich), September $12^{\text {th }}$ 2000.

${ }^{25}$ Interview: Board Representative, Sinopec Head Quarters, Beijing August $12^{\text {th }} 2004$.

26 “Exxon adds 500-outlet to deal to Sinopec stake,” FT, September $12^{\text {th }} 2000$.

${ }^{27}$ See "BOC and CCB overhaul top management" FT July $28^{\text {th }} 2004$.

28 “Chinese Lessons” Far Eastern Economic Review, August 12 1993.

${ }^{29}$ Interview: Board Representative, Sinopec Head Quarters, Beijing, August $12^{\text {th }} 2004$.

${ }^{30}$ Interview: Board Representative, Sinopec Head Quarters, Beijing, August $12^{\text {th }} 2004$.

${ }^{31}$ Interview: Executive Director, Bank of China (Hong Kong), Hong Kong, July $20^{\text {th }} 2004$.

${ }^{32}$ BOC (HK) Press Release, August $16^{\text {th }} 2004$.

${ }^{33}$ Xinhua Financial Network (XFN) and Shanghai Far East Credit Rating Co. Ltd (Far East) started to rank credit risks of China's listed companies in January 2002, named as the XFN-Far East China Credit Rating. The rating is based on international standards and pays a special attention to corporate governance concerns given the generally perceived poor standards of corporate governance in Chinese companies (XFN, 2002).

${ }^{34}$ See "HKMA widens the Net in BOC Probe” The Standard (HK), August 6 2004.

${ }^{35}$ HKMA Deputy Chief Executive HKMA as reported in SCMP June 14th 2003.

36 "Some Considerations in the Study of Monetary Policy Transmission” Zhou Xiaochuan Governor, People's Bank of China, May $12^{\text {th }} 2004$

37 “Vice premier emphasizes introduction of best banking practice” Peoples Daily July $1^{\text {st }} 2004$.

38 “China grants permission to solely owned banks to list after reformation” Peoples Daily, February $9^{\text {th }} 2002$. 
International listing as a means to mobilize the benefits of financial globalization:

Micro-level evidence from China

\section{References}

Allen, F., Qian, J. \& Qian, M. (2005). Law, Finance, and Economic Growth in China. Journal of Financial Economics, 77 (1), 57-116.

Amsden, A. (2001). The rise of "the rest": challenges to the west from late-industrializing economies. Oxford: Oxford University Press.

Bates, B. (1997). Learning from the Evolution of Telecommunications in the Developed World. In P. Lee, (Ed.), Telecommunications and Development in China (pp. 21-53). New Jersey: Hampton.

Black, B. (2001). Does Corporate Governance Matter? A Crude Test Using Russian Data. University of Pennsylvania Law Review, 149, 2131-2150.

Business Week Online http://www.businessweek.com/

Cheffins, B. (2000). Putting Britain on the Roe Map. The Emergence of the Berle-Means Corporation in the United Kingdom. Available at SSRN: http://ssrn.com/abstract=218655

Clay, K. \& Wright, G. (2005). Order without Law: Property Rights during the California Gold Rush. Explorations in Economic History, 42, 155-183.

CLSA, (2004). CLSA Corporate Governance Watch, CLSA September 2004.

Coffee, J. (2001). The Rise of Dispersed Ownership: The Roles of Law and the State in the Separation of Ownership and Control. The Yale Law Journal, 111 (1), 1-82.

Coffee, J. (2002). Racing Towards the Top: The Impact of Cross-Listing and Stock Market Competition on International Corporate Governance. Columbia Law Review, 102, 1757-1831.

Demsetz, H. (1968). Why Regulate Utilities? Journal of law and Economics, 11(1), 55-65.

Dewenter, K., \& Malatesta, P. (2001). State-Owned and Privately-Owned Firms: An Empirical Analysis of Profitability, Leverage, \& Labor Intensity. American Economic Review, 91, 320-334.

Dillon, T.H. (1925). Some Aspects of Utility Regulation. Harvard Business Review, 32-39.

Glaeser, E., La Porta, R., Lopez-de-Silanes, F. \& Shleifer, F. (2004). Do Institutions Cause Growth? National Bureau of Economic Research Paper W10568.

Green, S. (2004). The Development of China's Stock Market, 1984-2002: Equity Politics and Market Institutions, London: RoutledgeCurzon.

Hsu, R. (1991). Economic Theories in China, 1979-1988. New York: Cambridge University Press. 
Kambara, T., \& Howe, C. (2007). China and the Global Energy Crisis, Cheltenham: Edward Elgar.

Kirkpatrick, C., \& Parker, D. (2004). Regulatory Impact Assessment and Regulatory Governance in Developing Countries. Public Administration and Development, 24 (4), 333-344.

Klapper, L., \& Love, I. (2004). Corporate Governance, Investor Protection, \& Performance in Emerging Markets. Journal of Corporate Finance, 10 (5), 703-28.

Korczak, P., \& Bohl, M. (2005). Empirical Evidence on Cross-Listed Stocks of Central and Eastern European Companies. Emerging Markets Review, 6 (2), 121-37.

Kose, M., Prasad, E., Rogoff, K., \& Wei, S. (2007). Financial Globalization beyond the Blame Game: A New Way of Looking at Financial Globalization Reexamines Its Costs and Benefits. Finance and Development, 44 (1), 9-13.

Kose, M, Prasad, E., Rogoff, K., \& Wei, S. (2006). Financial Globalization: A Reappraisal. IMF Working Paper (WP/06/189).

La Porta, R., Lopez-De Silanes, F., Shleifer, A., \& Vishny, R. (2000). Investor Protection and Corporate Governance. Journal of Financial Economics, 58 (1), 3-27.

Leventhal, D. (1991). Organizational Adaptation and Environmental Selection-Interrelated Processes of Change. Organization Science, 2(1), 140-145.

McKinnon, R. (1991). The Order of Economic Liberalization: Financial Control in the Transition to a Market Economy. London: John Hopkins University Press.

McKinsey Global Institute (2006). Putting China's Capital to Work: The Value of Financial System Reform, McKinsey \& Company, May 2006.

Michie, R. (1987). The London and New York Stock Exchanges, 1850-1914. London: Allen \& Unwin. Mishkin, F. (2006). The Next Great Globalization. New Jersey: Princeton University Press.

Neal, L. (1987). The Integration and Efficiency of the London and Amsterdam Stock Markets in the Eighteenth Century. The Journal of Economic History, 47 (1), 97-115.

Nolan, P. (2001). China and the Global Business Revolution. Palgrave: Basingstoke.

Nolan, P. (2004). China at the Crossroads. Cambridge: Polity Press. 
International listing as a means to mobilize the benefits of financial globalization:

Micro-level evidence from China

Pagano, M., Roell, A., \& Zechner, J. (2002). The Geography of Equity Listing: Why do Companies List Abroad? The Journal of Finance, 57 (6), 2651-2694.

Peoples Daily (English Version) http://english.peopledaily.com.cn/

Pistor, K., Raiser, M., \& Gelfer, S. (2000). Law and Finance in Transition Economies. Economics of Transition, 8 (2), 325-368.

Poon, W. \& Chan, K. (2007). An Empirical Examination of the Informational Content of Credit Ratings in China. Lingnan University: http://asianfa.org/Paper/07china_ratings2.14nfinaln.pdf.

Pratt, J., (1980). The Petroleum Industry in Transition: Antitrust and the Decline of Monopoly Control in Oil. The Journal of Economic History. 40 (4), 815-837.

Ravillion, M. (2006). Looking Beyond Averages in the Trade and Poverty Debate. World Development, 34 (8), 1374-1392.

Rodrik, D. (2001). Developing Countries Hazardous Obsession with Global Integration. Foreign Policy, March/April 2001.

Roe, M. (2005). Regulatory Competition in Making Corporate Law in the US-and its Limits. Oxford Review of Economic Policy, 21(2), 232-242.

Schenk, C. (2007). Economic and Financial Integration between Hong Kong and Mainland China before the Open Door Policy 1965-75. Hong Kong Institute of Monetary Research: https://www.hkimr.org/conferences_detail.asp?id=27\&callfrom=previous\&page=1

Schubert, E. (1988). Innovations, Debts, and Bubbles: International Integration of Financial Markets in Western Europe, 1688-1720. The Journal of Economic History, 48 (2), 299-306.

South China Morning Post (SCMP) www.scmp.com

Stiglitz, J. (2000). Capital Market Liberalization, Economic Growth and Instability. World Development, 28 (6), 1075-1086.

Supple, B. (1976). The State and the Industrial Revolution 1700-1914. In C. Cipolla (Ed.), The Industrial Revolution 1700-1914, The Fontana Economic History of Europe, Volume 3, pp. 301353, Sussex: Harvester Press. 
Sun, L., \& Tobin, D. (2005). International Listing as a Mechanism of Commitment to More Credible Corporate Governance Practices: the case of the Bank of China (Hong Kong). Corporate Governance: An International Review, 13(1), 81-91.

Sun, Q., \& Tong, W. (2003). China Share issue Privatization: The Extent of Its Success. Journal of Financial Economies, 70, 183-222.

The Standard (Hong Kong), www.thestandard.com.hk.

UNCTAD (2006). 2006 Review of the Implementation Status of Corporate Governance Disclosure. available at www.unctad.org/en/docs/c2isarcrp3 en.pdf.

Wade, R. (2004). Is Globalization Reducing Poverty and Inequality? World Development, 32(4), 567589.

Wang, X., Xu, L., \& Zhu, T. (2004). State-Owned Enterprises Going Public: The Case of China. Economics of Transition, 12 (3): 467-87.

Williams, B. (1975). The Chinese Petroleum Industry. China: A Reassessment of the Economy, Joint Economic Committee of the United States, $10^{\text {th }}$ July 1975, 225-263.

Wu, C. (2006). Stock Market Integration between the Hong Kong SAR and the Peoples Republic of China, Unpublished doctoral dissertation, Queen Mary College, University of London.

Xi, C. (2006a). In search of an Effective Monitoring Board Model. Connecticut Journal of International Law, 22 (Fall), 1-46.

Xi, C. (2006b). Institutional Shareholder Activism in China: Law and Practice (Part 2). International Company and Commercial Law Review, 17, 287-294.

Xinhua Financial Network (2002). Credit Ratings Methodology: XFN-Far East China Credit Rating, www.xfn.com/creditrating/.

Zhu, S. (2001). Securities Regulation in China, Ardsley (NY): Transnational Publishers. 
Figure 1. Impact of financial globalization on developing countries: Recent revision on assessment framework

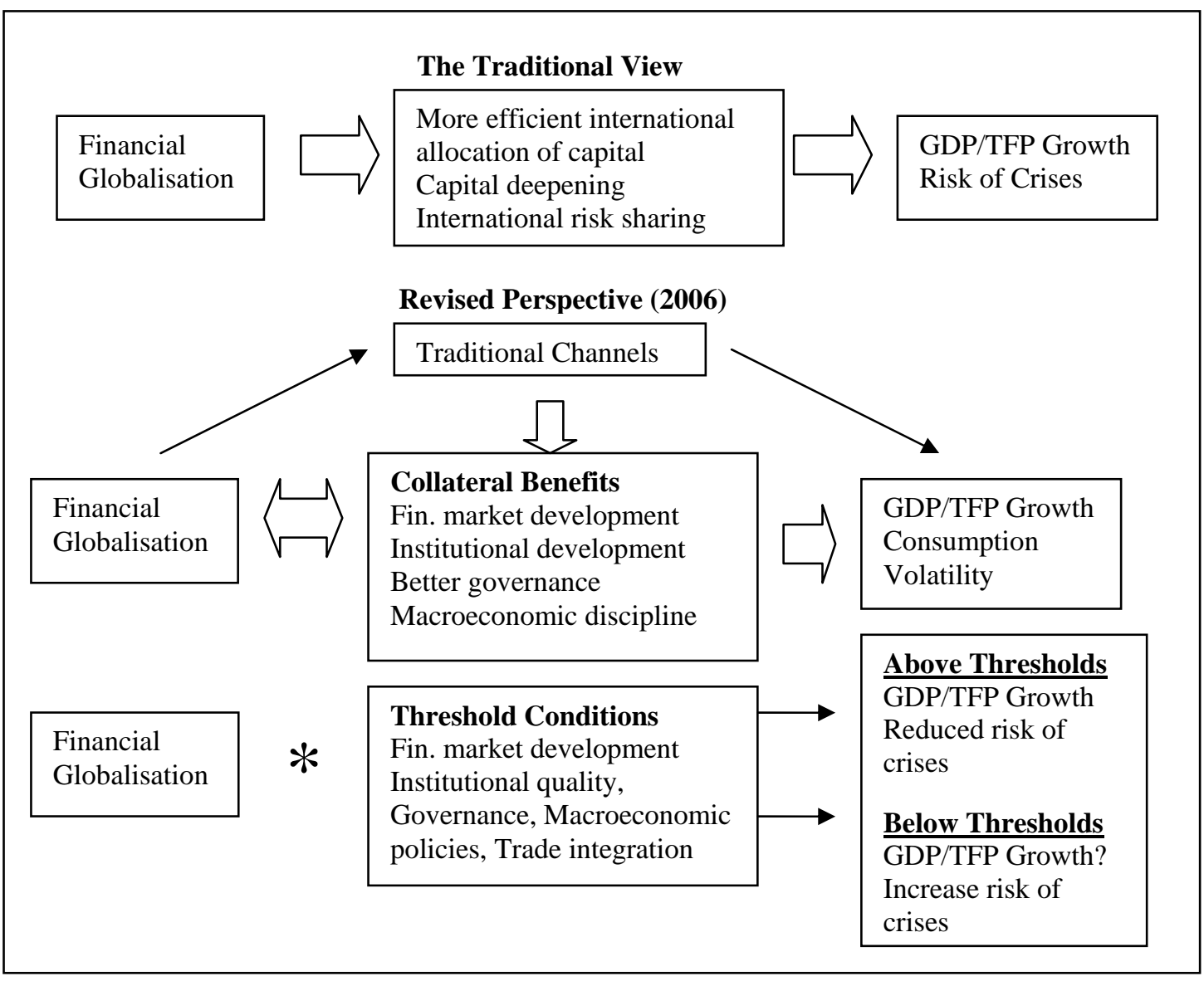

Figure 2: Impact of financial globalization on developing countries: A Firm Level Perspective on assessment framework

Financial

Globalisation

(Macro level)

Financial

Globalisation

(Firm level)

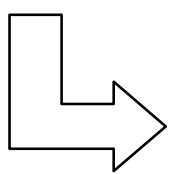

\section{Threshold Conditions}

Fin. market development

*

Institutional quality,

Governance, Macroeconomic

policies, Trade integration

\section{Intermediary}

Mechanisms

External monitoring

Bonding \& Self-

regulation

Financial innovations

\section{Direct Benefits}

Access to finance

Better governance practices

GDP/TFP Growth

Reduce risk of crises

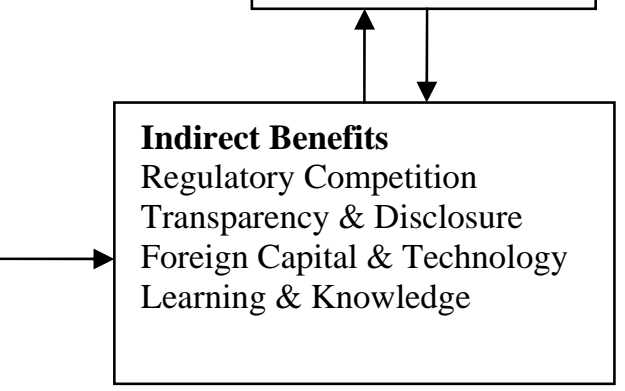


Figure 3: Price Earnings Rations of the Hang Seng, H-share \& Shanghai A-share Indices

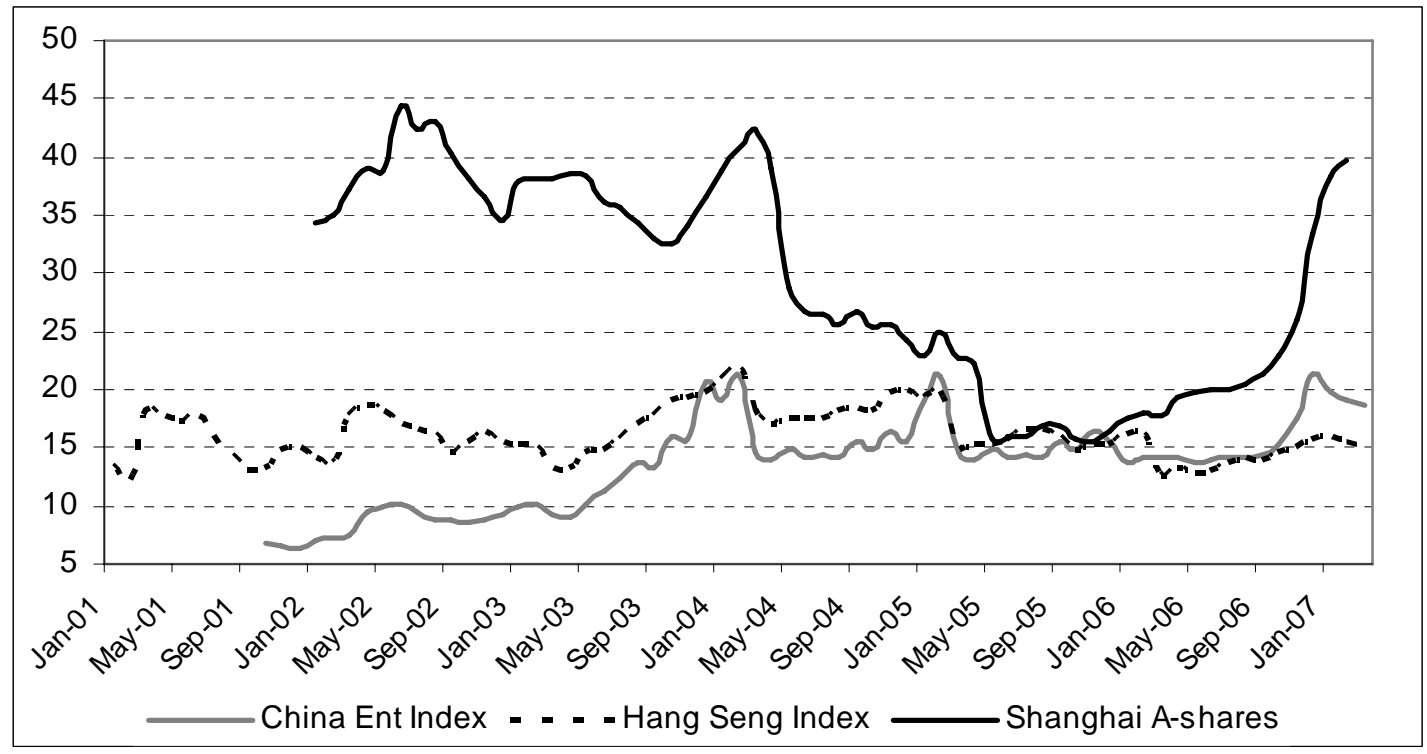

Source: HSI Services and China Securities Regulatory Commission.

Table 1: Average Corporate Governance Scores of Asian Companies by Country

\begin{tabular}{|c|c|c|c|c|c|}
\hline Country & $\begin{array}{l}\text { Country } \\
\text { score }\end{array}$ & $\begin{array}{l}\text { Average } \\
\text { company } \\
\text { score }\end{array}$ & $\begin{array}{l}\text { Average } \\
\text { company } \\
\text { scores } \\
\text { Quartile } 4\end{array}$ & $\begin{array}{l}\text { Average } \\
\text { company } \\
\text { scores } \\
\text { Quartile } 1\end{array}$ & $\begin{array}{l}\text { Difference } \\
\text { (Q4-Q1) }\end{array}$ \\
\hline Singapore & 7.5 & 61.1 & 70.6 & 49.9 & 20.7 \\
\hline Hong Kong & 6.7 & 64.2 & 75.2 & 52.1 & 23.1 \\
\hline India & 6.2 & 54.9 & 70.3 & 39.3 & 31 \\
\hline Malaysia & 6.0 & 62.5 & 75.4 & 48.9 & 26.5 \\
\hline Korea & 5.8 & 56.8 & 73.8 & 38.2 & 35.6 \\
\hline Taiwan & 5.5 & 54.9 & 68.4 & 40.8 & 27.6 \\
\hline Thailand & 5.3 & 62.0 & 73.2 & 48.8 & 24.4 \\
\hline Philippines & 5.0 & 56.3 & 80.4 & 20.2 & 60.2 \\
\hline China & 5.3 & 51.0 & 64.3 & 36.7 & 27.6 \\
\hline Indonesia & 5.3 & 44.3 & 59.6 & 30.9 & 28.7 \\
\hline
\end{tabular}

Source: Data from CLSA (2004: 130) 
International listing as a means to mobilize the benefits of financial globalization:

Micro-level evidence from China

Table 2: Equity Funds Raised by Listing on Hong Kong Stock Exchange, 1993-2007 (HK\$ million) ${ }^{\mathrm{a}}$

\begin{tabular}{rrrrr}
\hline Year & No of IPOs & $\begin{array}{c}\text { Fund raised on } \\
\text { IPOs }\end{array}$ & $\begin{array}{c}\text { Fund raised post } \\
\text { IPOs }\end{array}$ & Total fund raised \\
\hline 1993 & 10 & $9,092.04$ & 14128.71 & 23220.75 \\
1994 & 14 & $11,421.18$ & 11685.17 & 23106.35 \\
1995 & 2 & $3,581.10$ & 6083.86 & 9664.96 \\
1996 & 12 & $10,261.46$ & 16619.31 & 26880.77 \\
1997 & 25 & $71,432.34$ & 42636.69 & 114069.04 \\
1998 & 3 & $2,214.74$ & 18712.63 & 20927.37 \\
1999 & 7 & $6,249.22$ & 53191.82 & 59441.04 \\
2000 & 5 & $95,847.15$ & 249562.21 & 345409.36 \\
2001 & 6 & $17,630.92$ & 7518.44 & 25149.36 \\
2002 & 5 & $37,824.16$ & 31771.67 & 69595.83 \\
2003 & 11 & $49,214.99$ & 2522.19 & 51737.18 \\
2004 & 12 & $54,565.38$ & 31046.63 & 85612.01 \\
2005 & 13 & $138,222.23$ & 42846.02 & 181068.25 \\
2006 & 19 & $292,790.48$ & 61800.44 & 354590.92 \\
$2007^{\mathrm{b}}$ & 8 & $52,687.69$ & 43003.56 & 95691.25 \\
\hline
\end{tabular}

Note: ${ }^{a}$ Including both $\mathrm{H}$-share listing of enterprises incorporated in China and "red chips" listing of Chinese enterprises incorporated in Hong Kong. ${ }^{\mathrm{b}}$ Provisional figures up to August 2007.

Source: China Dimension in Data and Statistics of Hong Kong Sock Exchange’s website, http://www.hkex.com.hk/.

Table 3: A Summary of the Long-Term Profitability of H-shares

\begin{tabular}{|c|c|c|c|c|}
\hline $\begin{array}{l}\text { Performance } \\
\text { Proxy }\end{array}$ & & $\begin{array}{l}\text { Pre-IPO } \\
\text { performance }\end{array}$ & $\begin{array}{l}3 \text { years post IPO } \\
\text { performance }\end{array}$ & $\begin{array}{l}5 \text { years post IPO } \\
\text { Performance }\end{array}$ \\
\hline \multirow{3}{*}{$\begin{array}{l}\text { RNP } \\
\text { Standardized } \\
\text { to } 1 \text { in year of } \\
\text { IPO }\end{array}$} & Median & 0.71 & 1.197 & 0.614 \\
\hline & $\begin{array}{l}\text { Mean } \\
\text { (Stan. Dev.) }\end{array}$ & $\begin{array}{r}0.907 \\
(0.664) \\
\end{array}$ & $\begin{array}{r}1.156 \\
(1.061) \\
\end{array}$ & $\begin{array}{r}0.947 \\
(1.307) \\
\end{array}$ \\
\hline & n. & 41 & 41 & 24 \\
\hline \multirow{3}{*}{$\begin{array}{l}\text { Real EBIT } \\
\text { Standardized } \\
\text { to } 1 \text { in year of } \\
\text { IPO }\end{array}$} & Median & 0.729 & 1.252 & 0.607 \\
\hline & $\begin{array}{l}\text { Mean } \\
\text { (Stan. Dev.) }\end{array}$ & $\begin{array}{r}0.935 \\
(0.877) \\
\end{array}$ & $\begin{array}{r}1.527 \\
(1.708) \\
\end{array}$ & $\begin{array}{r}1.173 \\
(1.411) \\
\end{array}$ \\
\hline & n. & 38 & 38 & 21 \\
\hline \multirow[t]{3}{*}{ EBIT/Sales } & Median & 0.160 & 0.143 & 0.099 \\
\hline & $\begin{array}{l}\text { Mean } \\
\text { (Stan. Dev.) }\end{array}$ & $\begin{array}{r}0.238 \\
(0.260) \\
\end{array}$ & $\begin{array}{r}0.237 \\
(0.255)\end{array}$ & $\begin{array}{r}0.214 \\
(0.279)\end{array}$ \\
\hline & n. & 42 & 42 & 28 \\
\hline
\end{tabular}

Note: This table presents the median, mean, standard deviation and number sampled (n.) for Real Net Profits (RNP), average Real Earnings before Interest \& Tax (EBIT), and EBIT/sales. The data was downloaded in July 2004. The sample covers all H-shares with a minimum of three years post privatization data.

Source: Taiwan Economic Journal database. 
Table 4: Credit Rating of China’s Listed Companies (on the main boards), August 2007

\begin{tabular}{|c|c|c|c|c|}
\hline \multirow[b]{2}{*}{ Rating } & \multicolumn{2}{|c|}{ International Listed Companies } & \multicolumn{2}{|c|}{ Domestic Listed Companies } \\
\hline & $\begin{array}{l}\text { No. of } \\
\text { Companies }\end{array}$ & $\begin{array}{l}\text { As \% of the rated } \\
\text { companies }\end{array}$ & $\begin{array}{l}\text { No. of } \\
\text { Companies }\end{array}$ & $\begin{array}{l}\text { As \% of the rated } \\
\text { companies }\end{array}$ \\
\hline AAA & 4 & & 0 & \\
\hline $\mathrm{AA}+$ & 2 & & 1 & \\
\hline AA & 5 & & 5 & \\
\hline AA- & 3 & & 8 & \\
\hline Subtotal & 14 & 38.9 & 14 & 8.5 \\
\hline$A+$ & 5 & & 10 & \\
\hline A & 1 & & 10 & \\
\hline A- & 2 & & 13 & \\
\hline Subtotal & 8 & 22.2 & 33 & 20.1 \\
\hline $\mathrm{BBB}+$ & 4 & & 15 & \\
\hline BBB & 2 & & 25 & \\
\hline BBB- & 3 & & 20 & \\
\hline Subtotal & 9 & 25.0 & 60 & 36.6 \\
\hline$<$ BBB- & 5 & 13.9 & 57 & 34.8 \\
\hline Total rated & 36 & 100.0 & 164 & 100.0 \\
\hline Total Listed & 152 & & 1434 & \\
\hline
\end{tabular}

Source: XFN-Far East China Credit Rating Table (www.xfn.com/creditrating/), accessed in July 2003, December 2006, September 2007. 


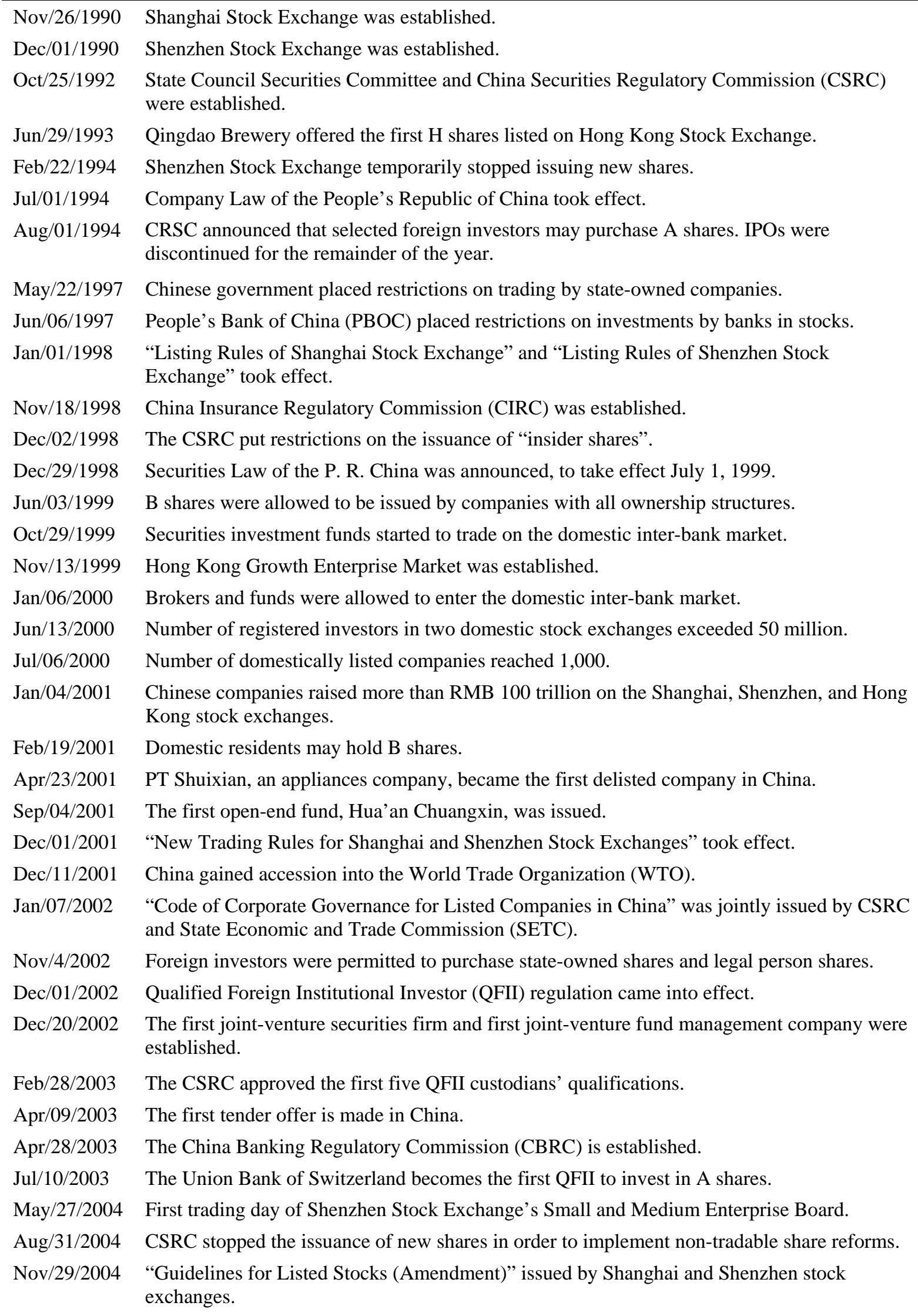

Feb/24/2005 First exchange-traded fund was listed. 
Apr/30/2005 Reform of non-tradable shares began in selected companies.

Jul/21/2005 RMB was revalued by 2\%. China adopted a managed float against a basket of currencies.

Nov/22/2005 Reform of non-tradable shares was completed on the Small and Medium Enterprise Board.

Jan/01/2006 Revised Securities Law and Companies Law took effect.

Jan/05/2006 G-share (of companies that have completed non-tradable share reform) index was launched and foreign investors may invest in $\mathrm{G}$ shares and newly listed companies.

Mar/07/2006 The Swiss cement producer Holchin B.V. became G share’s first foreign institutional investor.

Mar/21/2006 “Guidance on Articles of Association of Listed Companies” became effective.

May/08/2006 “Administrative Rules for Securities Offerings of Listed Companies” became effective.

May/15/2006 New trading rules adopted by Shanghai and Shenzhen stock exchanges.

May/18/2006 “Measures for the Administration of Initial Public Offerings and Listing of Stocks” took effect.

Jun/01/2006 Bank of China (BOC) has its first trading day on the Hong Kong Stock Exchange. The BOC IPO raises $\$ 11.2$ billion.

Jul/05/2006 Bank of China’s first trading day on the Shanghai Stock Exchange. BOC raises RMB 20 billion in its Shanghai IPO.

Oct/27/2006 The Industrial and Commercial Bank of China raises a combined \$21.9 billion in Hong Kong and Shanghai IPO.

Jan/31/2007 “Administrative Measures for the Disclosure of Information of Listed Companies” took effect.

Source: CSRC website at http://www.csrc.gov.cn/n575458/n575727/index.html. Xinhua Finance and Milken Institute (Nov. 2006), "Chinese Initial Public Offering: Background Brief,” available at www.milkeninstitute.org/chinaindicators/pdfs/InitialPubOffer.pdf. Lin et al. (2007), “The Development of Corporate Governance in China”, Company Lawyer, Vol. 28(7), pp. 195-203. 